Magda Urbańska

Uniwersytet Rzeszowski
Kiedy myślimy Rodzina..., red. M. Duda,

K. Kułek-Sładek, Kraków 2016, s. 397-414

(Praca Socjalna w Teorii i Działaniu, 2).

\title{
Pomoc i wsparcie dla rodzin zastępczych w środowisku lokalnym
}

\author{
Help and support for foster families \\ in the local community
}

\begin{abstract}
A family is the basic environment of education and childcare. However, when parents are not able to fulfil care and educational functions, tasks of a natural family are performed by foster care, carried out among by foster families. Admitting of the child to the own family is preceded by a process of qualifications and specialized training, organized for foster families by the organizer of family foster care. But even the best theoretical training cannot protect against a variety of behavioral prob-
\end{abstract}

lems and care which foster parents encounter, hence it becomes necessary to support and assistance the families who take the trouble to care for abandoned and orphaned children. The article presents the measures implemented to support foster families in the local community for the actions taken in 2012-2013 in the city of Rzeszów by the organizer of family foster care.

Keywords: a foster family, support, help, the local community

Opieka zastępcza nad dzieckiem, które nie może przebywać z własnymi rodzicami, wymaga kompleksowych działań wspierających, podejmowanych przez wszystkie podmioty działające na rzecz dziecka i rodziny. Jednym z najważniejszych elementów tego systemu są rodziny zastępcze sprawujące pieczę w warunkach zbliżonych do rodzinnych. Oprócz odpowiednich predyspozycji i motywa-

${ }^{1}$ Tekst stanowi rozszerzoną wersję części artykułu: Support for foster and adoptive families in the local community based on the example of the city of Rzeszów, [w:] Interdisciplinary approach in social problem solving, ed. I. Pesatova, B. Szluz, P. Walawender, Usti nad Labem 2015. 
cji do podjęcia opieki, a także zapewnienia warunków bytowych i mieszkaniowych rodzice zastępczy powinni przede wszystkim dawać rękojmię należytego sprawowania opieki i wychowania dziecka, niebędącego ich własnym. Odpowiednie funkcjonowanie rodziny zastępczej wymaga jednak systematycznego wsparcia i pomocy ze strony służb społecznych, nieograniczającego się do działań na etapie początkowym i oddziaływań interwencyjnych w sytuacjach problemowych. Rodzina zastępcza powinna być partnerem służb społecznych, a wsparcie z ich strony powinno odnosić się także do stałego wzmacniania kompetencji rodzicielskich rodzin zastępczych oraz pomocy w wypełnianiu funkcji opiekuńczo-wychowawczych. Działania te powinny być prowadzone z uwzględnieniem specyfiki i potrzeb danej rodziny zastępczej na poszczególnych etapach jej rozwoju oraz przy wykorzystaniu zasobów i możliwości środowiska lokalnego.

\section{Rodzina zastępcza - pojęcie, rys historyczny}

Rodzina zastępcza uważana jest za jedną z najbardziej korzystnych form opieki nad dzieckiem, które nie może przebywać z własnymi rodzicami. Jest to środowisko wychowawcze stworzone przez osoby niebędące rodzicami naturalnymi dziecka, w którym przebywają dzieci osierocone lub z innych przyczyn pozbawione właściwej opieki rodziców². Według Marka Safiana rodziny zastępcze to „środek opiekuńczy, którego celem jest zastąpienie dziecku wychowania w rodzinie własnej poprzez stworzenie warunków zbliżonych do tych, które istnieją w normalnie funkcjonującej rodzinie"3. Z prawnego punktu widzenia to oparta na modelu wychowania rodzinnego forma pieczy zastępczej nad dziećmi i młodzieżą pozbawionymi trwale lub tymczasowo pieczy rodziców ${ }^{4}$. Według Elżbiety Różańskiej i Aleksandra Tynelskiego rodziny zastępcze to „rodziny, które na pewien przejściowy okres biorą pod opiekę i wychowanie dziecko pozbawione rodziców lub dziecko znajdujące się w warunkach losowych zagrażających jego zdrowiu bądź rozwojowi

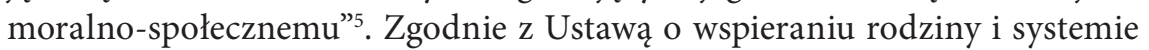
pieczy zastępczej rodziną zastępczą są małżonkowie lub osoby niepozostające w związku małżeńskim, u których umieszczono dziecko w celu sprawowa-

\footnotetext{
2 M. Jamrożek, B. Matyjas, Rodzina zastępcza, [w:] Encyklopedia pedagogiczna XXI wie$k u$, t. 5, red. T. Pilch, Warszawa 2006, s. 386, 388.

3 J. Matejek, Działalność ośrodków adopcyjno-opiekuńczych w procesie przygotowania i wspierania rodzin zastępczych, Kraków 2008, s. 31 .

4 L. Winogrodzka, Rodziny zastępcze i ich dzieci, Lublin 2007, s. 77.

5 A. Łuczyński, Rodziny zastępcze - ich rola i zadania w systemie opieki całkowitej, [w:] Opieka i wychowanie dzieci sierocych w Polsce, red. J. Kuźma, Kraków 2007, s. 73.
} 
nia nad nim pieczy zastępczej ${ }^{6}$. Najważniejszym celem rodziny zastępczej jest stworzenie stabilnego środowiska wychowawczego dla dzieci, które zostały takiego środowiska pozbawione ${ }^{7}$.

Funkcjonowanie rodziny zastępczej w Europie ma długoletnią tradycję, jednak instytucjonalną formę rodzina zastępcza przybrała w XVI wieku za sprawą św. Wincentego à Paulo, który umieszczał dzieci przebywające w sierocińcach u wiejskich kobiet. W Polsce do rozwoju tej formy opieki nad dziećmi osieroconymi, zwłaszcza porzuconymi niemowlętami, przyczynił się ks. Piotr Gabriel Baudouin (1689-1768), uważany za prekursora tworzenia rodzin zastępczych ${ }^{8}$. Stopniowo umieszczanie dzieci w rodzinach zastępczych coraz bardziej się upowszechniało, w coraz mniejszym stopniu wiążąc się z działalnością instytucji charytatywnych. Do wychowania w środowisku zastępczym zaczęto powracać dopiero po I wojnie światowej, bowiem w czasie rozbiorów kwestie opieki nad polskimi dziećmi regulowało ustawodawstwo poszczególnych państw-zaborców.

W niepodległej Polsce prawo do opieki i pomocy państwa dzieciom bez dostatecznej opieki rodzicielskiej oraz zaniedbanym pod względem wychowawczym wprowadziła Konstytucja Rzeczypospolitej Polskiej z 17 marca 1921 roku (art. 103) ${ }^{9}$. Od tego czasu wyróżnić można trzy okresy ewolucyjnych przemian w rozwoju i działalności rodzin zastępczych. Pierwszy z nich to okres do 1926 roku, kiedy nie obowiązywał system kwalifikacji dzieci i rodziców, co przekładało się na przypadki braku troski o zdrowie, wykształcenie i rozwój dzieci przebywających w rodzinach zastępczych. Wszystkie wydatki związane z działalnością opiekuńczą ponoszone były przez samorządy terytorialne i organizacje charytatywne, gdyż wydatki państwa na opiekę nad dziećmi były niewielkie. Drugi etap to lata 1926-1934, cechujący się ostrożnymi terytorialnymi (Łódź, Warszawa) eksperymentami w dziedzinie rodzinnej opieki zastępczej, stopniowo rozszerzając inicjatywy lokalne na cały kraj. W 1934 roku Ministerstwo Opieki Społecznej oficjalnie usankcjonowało rodzinną opiekę zastępczą nad dzieckiem. Trzeci etap przemian to lata 1934-1939, w których rodziny zastępcze przeżywały szczególny rozkwit. Etap ten został przerwany po wybuchu II wojny światowej, gdy działalność instytucji i organizacji opiekuńczych została zakazana, a sieroty i dzieci opuszczone znalazły schronienie w powstających spontanicznie rodzinach zastępczych. Po zakoń-

6 Art. 41.1 Ustawy z dnia 9 czerwca 2011 roku o wspieraniu rodziny i systemie pieczy zastępczej (Dz. U. 2011, nr 149, poz. 887).

7 Pkt. 0.5 Kodeksu Etycznego Rodzin Zastępczych, [w:] Pomoc dzieciom i rodzinie w środowisku lokalnym. Debata o nowym systemie, red. M. Racław-Markowska, Warszawa 2005, s. 203.

$8 \quad$ M. Jamrożak, B. Matyjas, Rodzina zastępcza..., dz. cyt., s. 386.

9 Tamże, s. 386; J. Matejek, Działalność ośrodków adopcyjno-opiekuńczych..., s. 38-39. 
czeniu działań wojennych kwestie opieki nad dzieckiem powyżej 3. roku życia oraz sprawy związane z organizacją rodzin zastępczych oraz kwalifikacją dzieci do tych rodzin zostały przekazane do Ministerstwa Oświaty. W 1946 roku powołano Departament Opieki nad Dzieckiem, do którego obowiązków należała także opieka nad dziećmi i młodzieżą w rodzinach zastępczych. Wydano także szczegółowe rozporządzenie dotyczące umieszczania dzieci w rodzinach zastępczych oraz wymagań stawianych rodzicom zastępczym ${ }^{10}$.

W latach 50. XX wieku nastąpiła stagnacja w funkcjonowaniu rodzin zastępczych. Spowodowane to było w głównej mierze umieszczaniem dzieci w różnego rodzaju zakładach opieki. Ponowne zainteresowanie rodziną zastępczą przypadło na lata 70., równocześnie z wprowadzeniem aktów prawnych odnoszących się do pomocy materialnej dla dzieci przebywających w rodzinach zastępczych oraz samych rodzin. Próbą całościowego uregulowania zasad umieszczania dzieci w rodzinach zastępczych, wymagań wobec kandydatów na rodziców zastępczych oraz zasad współdziałania sądów z organami administracyjnymi było rozporządzenie Rady Ministrów z 26 stycznia 1979 roku. Kolejne przepisy regulujące funkcjonowanie rodzin zastępczych zostały wprowadzone w 1991 roku oraz 1993 roku. W ich myśl w rodzinie zastępczej umieszczano dzieci całkowicie lub częściowo pozbawione opieki rodzicielskiej, które nie mogły być przysposobione, w tym dzieci odbiegające od normy rozwojowej, wymagające kształcenia specjalnego oraz pomocy profilaktyczno-wychowawczej i resocjalizacyjnej. W rodzinach zastępczych umieszczano także dzieci do lat dwóch, które oczekiwały na przysposobienie $^{11}$. W 1999 roku zadania związane z zastępczą opieką nad dzieckiem zostały przeniesione z resortu oświaty do pomocy społecznej. Ideą wyznaczającą kierunek opieki nad dzieckiem stało się przede wszystkim wspieranie rodziny naturalnej oraz ochrona jej przed koniecznością umieszczenia dzieci poza domem rodzinnym. Rodziny zastępcze stały się alternatywą w sytuacji, gdy jedynym rozwiązaniem było czasowe lub trwałe odłączenie od rodziców ${ }^{12}$. Ustawa o pomocy społecznej z 2000 roku wprowadziła podział na trzy typy rodzin zastępczych:

- rodziny, które na podstawie przepisów Kodeksu rodzinnego i opiekuńczego mogą być zobowiązane do dostarczania środków utrzymania (dziadkowie),

- rodziny, które na podstawie przepisów Kodeksu rodzinnego i opiekuńczego nie mogą być zobowiązane do dostarczania środków utrzymania (krewni, osoby obce),

10 Tamże, s. 39-43; L. Winogrodzka, Rodziny zastępcze..., dz. cyt., s. 68-71.

11 J. Matejek, Działalność ośrodków ..., dz. cyt., s. 45-48; M. Jamrożak, B. Matyjas, Rodzina zastępcza..., dz. cyt., s. 387.

12 Tamże, s. 387. 
- rodziny niezobowiązane do alimentacji, wykonujące zadania pogotowia rodzinnego ${ }^{13}$.

Zgodnie z Ustawą z 12 marca 2004 roku rodziny zastępcze dzieliły się na:

- spokrewnione z dzieckiem, w której opiekę przejmują bliżsi lub dalsi członkowie rodziny, np. dziadkowie, wujostwo itp.,

- niespokrewnione z dzieckiem, gdy opieka nad dzieckiem sprawowana jest przez osoby prawnie obce dla dziecka,

- zawodowe, niespokrewnione z dzieckiem, w tym: wielodzietne (w których w tym samym czasie umieszcza się 3-6 dzieci lub rodzeństwa wielodzietne), specjalistyczne (przeznaczone dla dzieci wymagających szczególnej opieki, np. niedostosowanych społecznie, chorych, z dysfunkcjami), o charakterze pogotowia rodzinnego (pobyt okresowy, do unormowania sytuacji życiowej dziecka $)^{14}$.

Od 1 stycznia 2012 roku na mocy Ustawy z 9 czerwca 2011 roku o wspieraniu rodziny i systemie pieczy zastępczej rodziny zastępcze mogą występować w formie:

- rodziny zastępcze spokrewnione, które tworzą małżonkowie lub osoby niepozostające w związku małżeńskim, będący wstępnymi lub rodzeństwem dziecka,

- rodziny zastępcze niezawodowe oraz rodziny zastępcze zawodowe, tworzone przez małżonków lub osoby niepozostające w związku małżeńskim, niebędące wstępnymi lub rodzeństwem dziecka (art. 41 pkt. 2 i 3 ).

Rodziny zastępcze zawodowe mogą mieć charakter pogotowia rodzinnego i specjalistyczny. W rodzinie zastępczej o charakterze pogotowia rodzinnego przyjmowane są dzieci na podstawie orzeczenia sądu, dzieci doprowadzone przez policję lub straż graniczną, a także na wniosek rodziców, dziecka lub innej osoby na podstawie art. 12a Ustawy z dnia 29 lipca 2005 roku o przeciwdziałaniu przemocy w rodzinie. W tego typu rodzinie dziecko przebywa do czasu unormowania swojej sytuacji, nie dłużej niż 4 miesiące. W uzasadnionych przypadkach okres ten może być wydłużony do 8 miesięcy lub do zakończenia postępowania sądowego o: powrót dziecka do rodziny, przysposobienie lub umieszczenie w rodzinnej pieczy zastępczej. W rodzinie specjalistycznej umieszcza się z kolei dzieci posiadające orzeczenie o niepełnosprawności, w tym o znacznym i umiarkowanym stopniu, dzieci na podstawie Ustawy z dnia 26 października

13 Tamże, s. 387-388.

14 R. Stojecka-Zuber, S. Badora, Opieka nad dziećmi w rodzinach zastępczych powiatu tarnobrzeskiego, [w:] Przeciw sieroctwu. Zapobieganie, opieka, pomoc instytucjonalna, red. S. Badora, Tarnobrzeg 2009, s. 152; B. Krajewska, Instytucje wsparcia dziecka i rodziny. Zagadnienia podstawowe, Kraków 2009, s. 66-70. 
1982 roku o postępowaniu w sprawach nieletnich oraz małoletnie matki z dziećmi. Wszystkie typy rodzin zastępczych otrzymują pomoc finansową związaną z pokryciem kosztów utrzymania dziecka. Wysokość świadczenia oraz różnego rodzaju dodatki uzależnione są od typu rodziny zastępczej i jej specjalności.

W rodzinie zastępczej zawodowej oraz rodzinie zastępczej niezawodowej może być umieszczonych nie więcej niż troje dzieci lub trzy osoby, które osiągnęły pełnoletniość, ale przebywają w pieczy zastępczej. W przypadku rodzeństwa jest możliwe zwiększenie tego limitu. Liczba dzieci w rodzinach zastępczych spokrewnionych uzależniona jest od konkretnej sytuacji rodzinnej. Decyzja o umieszczeniu dziecka w rodzinie zastępczej zapada na podstawie orzeczenia sądu, w postępowaniu będącym najczęściej konsekwencją ograniczenia, zawieszenia lub pozbawienia władzy rodzicielskiej rodziców dziecka ${ }^{15}$. W razie pilnej konieczności, na wniosek lub za zgodą rodziców dziecka możliwe jest umieszczenie dziecka w rodzinie zastępczej na podstawie umowy pomiędzy starostą a rodzina zastępczą, o czym powiadamiany jest sąd. Jest to jednak sytuacja znacznie rzadsza ${ }^{16}$.

Do wymagań stawianych rodzinom zastępczym należą:

- dają rękojmię należytego sprawowania pieczy zastępczej,

- nie byli i nie są pozbawieni władzy rodzicielskiej oraz władza rodzicielska nie jest im ograniczona ani zawieszona,

- wypełniają obowiązek alimentacyjny - w przypadku, gdy taki obowiązek w stosunku do nich wynika z tytułu egzekucyjnego,

- mają zdolność podejmowania czynności prawnych,

- są zdolni do sprawowania właściwej opieki nad dzieckiem (potwierdzone zaświadczeniem lekarskim o stanie zdrowia i opinią psychologa o posiadaniu predyspozycji i motywacji do pełnienia funkcji rodziny zastępczej),

- przebywają na terytorium Polski,

- zapewniają odpowiednie warunki bytowe i mieszkaniowe umożliwiające zaspokojenie indywidualnych potrzeb dziecka, w tym: rozwoju emocjonalnego, fizycznego i społecznego, właściwej opieki i rozwoju zainteresowań oraz wypoczynku i organizacji czasu wolnego,

- nie zostali skazani prawomocnym wyrokiem za umyślne przestępstwo (w przypadku rodzin niezawodowych i zawodowych),

- co najmniej jedna osoba tworząca rodzinę zastępczą ma stałe źródło dochodów (w przypadku rodzin niezawodowych),

- mają ukończone szkolenie organizowane przez organizatora rodzinnej pieczy zastępczej lub ośrodek adopcyjny (rodziny zawodowe, niezawodowe, w przypadku rodzin zastępczych spokrewnionych szkolenie pro-

15 L. Winogrodzka, Rodziny zastępcze..., dz. cyt., s. 75.

16 Tamże, s. 77. 
wadzone jest według indywidualnego planu, w zależności od potrzeb rodziny i dziecka),

- systematycznie podnoszą kwalifikacje poprzez szkolenia (rodziny zawodowe $)^{17}$.

Z danych Ministerstwa Sprawiedliwości wynika, że w latach 2004-2014 liczba dzieci, wobec których orzeczono umieszczenie w rodzinie zastępczej, pozostaje na stosunkowo stałym poziomie (od 2012 roku maleje), zauważalna staje się za to tendencja do znacznie rzadszego umieszczania dzieci w placówkach opiekuńczo-wychowawczych, będących formą instytucjonalnej pieczy zastępczej. Szczegółowe dane przedstawiono w tabeli 1.

Tabela 1. Liczba małoletnich umieszczonych w rodzinie zastępczej i placówkach opiekuńczo-wychowawczych w latach 2004-2014

\begin{tabular}{|c|c|c|}
\hline Rok & $\begin{array}{c}\text { Liczba małoletnich, } \\
\text { wobec których zarządzono } \\
\text { umieszczenie } \\
\text { w rodzinie zastępczej }\end{array}$ & $\begin{array}{c}\text { Liczba małoletnich } \\
\text { umieszczonych } \\
\text { w placówkach opiekuńczo- } \\
\text {-wychowawczych } \\
\text { wg orzeczenia do wykonania } \\
\text { (stan w ostatnim dniu } \\
\text { okresu sprawozdawczego) }\end{array}$ \\
\hline 2004 & 41754 & 26292 \\
\hline 2005 & 42855 & 25348 \\
\hline 2006 & 43785 & 25751 \\
\hline 2007 & 44412 & 24194 \\
\hline 2008 & 45150 & 21631 \\
\hline 2009 & 45907 & 21772 \\
\hline 2010 & 46145 & 20441 \\
\hline 2011 & 46197 & 20074 \\
\hline 2012 & 45946 & 19122 \\
\hline 2013 & 44379 & 19192 \\
\hline 2014 & 43164 & 18914 \\
\hline & & 9 \\
\hline
\end{tabular}

Opracowanie własne na podstawie: Ministerstwo Sprawiedliwości, Małoletni pod opieką rodziny zastępcze (karty Opm) w latach 1989-2014; Placówki opiekuńczo-wychowawcze umieszczenie małoletnich w latach 1989-2014, http://isws.ms.gov.pl/pl/baza-statystyczna/ opracowania-wieloletnie/ (24.06.2015).

17 Art. 42, 44, 51 Ustawy z dnia 9 czerwca 2011 roku o wspieraniu rodziny i systemie pieczy zastępczej. 
Zgodnie z art. 40 Ustawy o wspieraniu rodziny i systemie pieczy zastępczej głównym zadaniem rodziny zastępczej jest opieka nad dzieckiem oraz jego wychowanie. Zadania szczegółowe odnoszą się do: traktowania dziecka w sposób sprzyjający poczuciu godności i wartości osobowej, zapewnienia mu dostępu do świadczeń zdrowotnych, kształcenia, wyrównania braków rozwojowych i szkolnych oraz rozwoju uzdolnień i zainteresowań, zaspokajania potrzeb emocjonalnych, bytowych, rozwojowych, społecznych i religijnych dziecka, zapewnienie mu ochrony przed arbitralną lub bezprawną ingerencją w jego życie prywatne oraz umożliwienie kontaktu z rodzicami i osobami bliskimi, chyba że sąd postanowi inaczej. Ich obowiązkiem jest także współpraca z ośrodkiem adopcyjnym oraz koordynatorem i organizatorem rodzinnej pieczy zastępczej.

Rodzina zastępcza nie odbiega w swoim funkcjonowaniu od zadań rodziny biologicznej, jednak rodzice zastępczy nie zastępują w sensie prawnym rodziców naturalnych. Działania podejmowane w rodzinach zastępczych traktowane są jako dopełniające i uzupełniające wobec rodziny naturalnej, co wynika $\mathrm{z}$ faktu, że dziecko ma prawo żyć przede wszystkim w rodzinie biologicznej ${ }^{18}$. Zwraca się jednak uwagę, że ze względu na różnorodne dysfunkcje rodziny naturalnej dziecka rodziny zastępcze często podejmują także działania o charakterze kompensacyjno-terapeutycznym, co związane jest z trudnościami adaptacyjnymi dziecka, jego niedostosowaniem społecznym oraz zaburzeniami osobowości, spowodowanymi traumatycznymi przeżyciami ${ }^{19}$. Szczególna rola przypada rodzinom zastępczym zawodowym specjalizującym się w opiece nad dziećmi wymagającymi szczególnej troski ze względu na stan zdrowia psychicznego lub fizycznego oraz sprawującym opiekę nad dziećmi, które zdradzają przejawy demoralizacji lub są demoralizacją zagrożone. Stąd też konieczne wydaje się wsparcie rodzin zastępczych przez służby społeczne, począwszy od etapu kandydowania, poprzez szkolenia i specjalistyczne podnoszenie kwalifikacji oraz pomoc w sytuacji trudności opiekuńczo-wychowawczych.

\section{Działania wspierajace i pomocowe kierowane do rodzin zastępczych na terenie Rzeszowa}

Umieszczenie dziecka w rodzinie zastępczej jest sytuacją trudną zarówno dla samego dziecka, jak i rodziny zastępczej. Trudności te wynikają z dwóch to-

18 J. Maciaszek, Model rodzicielskiej opieki zastępczej - założenia a ich praktyczna realizacja, [w:] Przemiany wspótczesnej rodziny polskiej, red. S. Pelc, Rzeszów 2010, s. 173.

19 A. Łuczyński, Rodziny zastępcze..., dz. cyt., s. 74. 
czących się równolegle do siebie procesów, związanych z dzieckiem i rodzicami zastępczymi. Z perspektywy dziecka trudności są związane z separacją dziecka od rodziny własnej, przejściem dziecka do rodziny zastępczej oraz włączeniem go w nowy system rodzinny. Rodzi to u dziecka silne emocje: smutek, poczucie osamotnienia i opuszczenia, poczucie winy, obarczanie siebie odpowiedzialnością za utratę rodziny, wrogość, lęk o przetrwanie oraz wstyd ${ }^{20}$. Do tego dochodzi także brak zaufania, strach przed bliskością, nieumiejętność tworzenia więzi emocjonalnych, chłód uczuciowy, niechęć i wrogość oraz agresja wobec rodziców, rówieśników i rodzeństwa, a także podatność na negatywne wpływy środowiska pozarodzinnego ${ }^{21}$. Z badań Józefy Brągiel i Alicji Kurcz wynika, że okresie adaptacji do warunków rodziny zastępczej zachowania trudne dzieci to: agresja (wobec rówieśników, przedmiotów, samego siebie), nieposłuszeństwo i bunt, wulgaryzm, nadpobudliwość i nerwowość, nieumiejętność nawiązania kontaktu, bierność i apatia, unikanie kontaktu z rówieśnikami, lepkość i zmienność uczuciowa, nieumiejętność zrozumienia ograniczeń, ucieczki ze szkoły oraz kradzieże ${ }^{22}$. Problemami stwarzanymi przez dziecko są także trudności z nauką i nieposłuszeństwo $^{23}$. Sytuacje trudne, związane z przyjęciem dziecka, nie omijają także rodzin zastępczych. $\mathrm{Z}$ ich perspektywy problemem może być: nieumiejętność obdarzenia dziecka uczuciem, strach przed przywiązaniem się i nawiązaniem bliskich więzi emocjonalnych, trudność w kontaktach dzieci będących pod opieką z dziećmi własnymi oraz oczekiwania i brak wdzięczności ze strony wychowanka. Trudnościom tym towarzyszy lęk o przyszłość dzieci i ich bezpieczeństwo, bezsilność, złość i zniecierpliwienie ${ }^{24}$. Z badań Beaty Baron wynika, że trudności mogą być także związane z koniecznością niemal całodobowej opieki nad wychowankami oraz brakiem prywatności i intymności ${ }^{25}$. Trudności po obu stronach wiążą się także z wiekiem dziecka, długością czasu spędzonego w placówce wychowawczej, więzią z rodziną biologiczną

20 Z. W. Stelmaszuk, Dziecko $w$ rodzinie zastępczej, [w:] Rodzice i dzieci - psychologiczny obraz sytuacji problemowych, red. E. Milewska, A. Szymanowska, Warszawa 2000, s. $108-109$.

$21 \quad$ Miejski Ośrodek Pomocy Społecznej w Rzeszowie, Sprawozdanie z realizacji zadań z zakresu wspierania rodziny i systemu pieczy zastępczej za 2013 rok, Rzeszów 2014, s. 12.

22 J. Brągiel, A. Kurcz, Sytuacja szkolna dzieci z rodzin zastępczych, [w:] W świecie dziecka osieroconego i rodziny adopcyjnej, red. A. Kalus, Opole 2003, s. 14-15.

23 L. Winogrodzka, Rodziny zastepcze..., dz. cyt., s. 139-140.

24 Miejski Ośrodek Pomocy Społecznej w Rzeszowie, Sprawozdanie z realizacji..., dz. cyt., s. 12 .

25 B. Baron, Rodzicielstwo zastepcze w historii i praktyce, [w:] Świat rodziny. Perspektywa interdyscyplinarna wobec wyzwań i zagrożeń, red. J. M. Garbula, A. Zakrzewska, W. Sawczuk, Toruń 2013, s. 39-40. 
i czynnikami adaptacyjnymi do nowych warunków wychowawczych ${ }^{26}$. Sytuacja każdej rodziny zastępczej jest więc inna i wymaga indywidualnego podejścia ze strony wszystkich osób zaangażowanych.

Wsparcie rodzin zastępczych powinno zatem obejmować nie tylko doraźną pomoc w sytuacjach trudnych, ale też systematyczne pomaganie. Jak jednak wskazuje Dobroniega Trawkowska, szczególnie trudna jest praca z rodzinami spokrewnionymi, które są w podeszłym wieku, z niskimi kompetencjami opiekuńczo-wychowawczymi, dla których pracownicy służb pomocowych nie są autorytetami z powodu młodego wieku ${ }^{27}$. Współpracę z pracownikami socjalnymi wspierającymi rodziny zastępcze utrudniają ponadto trudności w komunikacji, związane z brakiem czasu, chęci do współpracy, wzajemnej wiedzy, brakiem adekwatnego języka opisu, związanym z formalnym i „urzędniczym" językiem używanym w odniesieniu do pracy pracownika socjalnego oraz zbiurokratyzowaniem pracy, co stanowi przeszkodę w tworzeniu partnerstwa $z$ rodzinami zastępczymi ${ }^{28}$. Dla lepszego zorganizowania wsparcia i pomocy rodzinom zastępczym Stowarzyszenie Zastępczego Rodzicielstwa opracowało Kartę Podstawowych Praw Rodziców Zastępczych, na której mocy rodziny zastępcze mają prawo m.in. do otrzymania wsparcia od pracowników sądów i instytucji odpowiedzialnych za pomoc rodzinie i dziecku, do pomocy w przygotowaniu dziecka do usamodzielnienia i opuszczenia rodziny, szkoleń podnoszących umiejętności opiekuńczo-wychowawcze oraz całodobowej pomocy w przezwyciężaniu sytuacji kryzysowych w rodzinie ${ }^{29}$. Rodzina zastępcza powinna także, nawet w sytuacjach krytycznych, współpracować ze służbami społecznymi i profesjonalistami w celu wypracowania rozwiązań zgodnych z dobrem dziecka. Obowiązkiem rodziny zastępczej jest ponadto stałe pogłębianie wiedzy, zwłaszcza w zakresie opieki i resocjalizacji, ale również jej prawem jest sięganie po pomoc wykwalifikowanych specjalistów ${ }^{30}$.

26 B. Sarnacka, Sieroctwo dziecka i możliwości jego kompensacji w systemie opieki, w: Pedagog i pracownik socjalny wobec wyzwań współczesności, red. A. Błasiak, E. Dybowska, N. Pikuła, Kraków 2012, s. 230-231.

27 D. Trawkowska, Pomoc społeczna i jej pracownicy wobec problemów pracy socjalnej z rodzinami zastępczymi, [w:] Pomoc dzieciom i rodzinie w środowisku lokalnym. Debata o nowym systemie, red. M. Racław-Markowska, Warszawa 2005, s. 159.

28 P. Sobisiak, „Nic o nas bez nas”. W stronę partnerskiego modelu wspótpracy rodzin zastępczych z pracownikami socjalnymi, [w:] Pomoc dzieciom i rodzinie w środowisku lokalnym..., dz.cyt., s. 165.

29 Stowarzyszenie Zastępczego Rodzicielstwa, Karta Podstawowych Praw Rodziców Zastępczych, [w:] Pomoc dzieciom i rodzinie w środowisku lokalnym..., dz. cyt, Warszawa 2005, s. 209.

30 Pkt. 0.8, 7.1, 7.3 Kodeksu Etycznego Rodzin Zastępczych, dz. cyt., s. 204-207. 
W mieście Rzeszowie funkcjonuje aktualnie 120 rodzin zastępczych, w których przebywa $155 \mathrm{dzieci}^{31}$. Z roku na rok liczba rodzin zastępczych, zwłaszcza niezawodowych i zawodowych wzrasta. Mimo to potrzeby Rzeszowa są jeszcze większe, zwłaszcza w zakresie rodzin zastępczych specjalistycznych, pełniących opiekę nad dziećmi niepełnosprawnymi oraz $\mathrm{w}$ formie pogotowia rodzinnego dla dzieci pozostawionych przez rodziców ${ }^{32}$. Najbardziej liczną grupą rodzin zastępczych są osoby spokrewnione, najbliższe dziecku dziadkowie lub pełnoletnie rodzeństwo. Szczegółowe dane zostały zaprezentowane w tabeli 2 .

Tabela 2. Liczba rodzin zastępczych w Rzeszowie w latach 2005-2014

\begin{tabular}{|c|c|c|c|c|}
\hline Rok & $\begin{array}{c}\text { Liczba rodzin } \\
\text { zastępczych } \\
\text { ogółem }\end{array}$ & $\begin{array}{c}\text { W tym rodzin } \\
\text { zastępczych } \\
\text { spokrewnionych }\end{array}$ & $\begin{array}{c}\text { W tym rodzin } \\
\text { zastępczych } \\
\text { niezawodowych }\end{array}$ & $\begin{array}{c}\text { W tym rodzin } \\
\text { zastępczych } \\
\text { zawodowych }\end{array}$ \\
\hline 2005 & 112 & 103 & 9 & 0 \\
\hline 2006 & 112 & 103 & 9 & 0 \\
\hline 2007 & 123 & 115 & 8 & 0 \\
\hline 2008 & 123 & 114 & 9 & 0 \\
\hline 2009 & 116 & 102 & 14 & 0 \\
\hline 2010 & 124 & 107 & 17 & 0 \\
\hline 2011 & 123 & 108 & $15^{*}$ & $00^{*}$ \\
\hline 2012 & 106 & 66 & 39 & 1 \\
\hline 2013 & 114 & 75 & 34 & 5 \\
\hline 2014 & 120 & bd & bd & bd \\
\hline
\end{tabular}

*Ustawa z dnia 9 czerwca 2011 roku o wspieraniu rodziny i systemie pieczy zastępczej zmieniła status rodzin zastępczych niespokrewnionych na rodziny zastępcze niezawodowe, a rodzin

31 Główny Urząd Statystyczny, Bank Danych Lokalnych - Opieka nad dziećmi i młodzieżą. Rodziny zastępcze. Powiat m. Rzeszów za rok 2014, http://stat.gov.pl/bdl/app/dane_ podgrup.dims?p_id=897233\&p_token=0.7033370941007369 (31.05.2015).

${ }_{32}$ W 2013 roku na Podkarpaciu ponad 2 tys. rodzin zastępczych opiekowało się ok. 3 tys. dzieci, które z różnych powodów nie mogły być ze swoimi rodzicami biologicznymi. W wywiadach radiowych pracownicy Miejskiego Ośrodka Pomocy Społecznej w Rzeszowie wskazują, że potrzebnych jest 6-7 rodzin zastępczych specjalistycznych dla dzieci $\mathrm{z}$ niepełnosprawnością oraz w formie pogotowia dla dzieci porzuconych. Brakuje rodzin zastępczych na Podkarpaciu, http://wiadomosci.onet.pl/rzeszow/brakuje-rodzin-zastepczychna-podkarparpaciu/pmrx3 (31.05.2015); B. Szlachcińska, Coraz więcej dzieci potrzebuje rodziców zastępczych, http://supernowosci24.pl/coraz-wiecej-dzieci-potrzebuje-rodzicowzastepczych/ (31.05.2015). 
zastępczych zawodowych wielodzietnych, specjalistycznych i o charakterze pogotowia rodzinnego na rodziny zastępcze zawodowe o charakterze pogotowia rodzinnego i specjalistyczne.

Źródło: Miejski Ośrodek Pomocy Społecznej w Rzeszowie, Program budowania lokalnego systemu opieki nad dzieckiem i rodzina w mieście Rzeszów na lata 2009-2015, Rzeszów 2009, s. 15; Miejski Ośrodek Pomocy Społecznej w Rzeszowie, Powiatowy Program Rozwoju Pieczy Zastępczej na lata 2012-2014, Rzeszów 2012, s. 8-9, Miejski Ośrodek Pomocy Społecznej w Rzeszowie, Sprawozdanie z realizacji zadań z zakresu wspierania rodziny i systemu pieczy zastępczej za 2012 rok, Rzeszów 2013, s. 9; Miejski Ośrodek Pomocy Społecznej w Rzeszowie, Sprawozdanie $z$ realizacji działań $z$ zakresu wspierania rodziny i systemu pieczy zastępczej za 2013 rok, Rzeszów 2014, s. 10; Główny Urząd Statystyczny, Bank Danych Lokalnych - Opieka nad dziećmi i młodzieżą. Rodziny zastępcze. Powiat m. Rzeszów za rok 2014, http://stat.gov. pl/bdl/app/dane_podgrup.dims?p_id=897233\&p_token=0.7033370941007369 (31.05.2015).

W mieście Rzeszowie do najczęstszych powodów umieszczania dzieci w rodzinach zastępczych należą:

- osierocenie,

- porzucenie,

- niepełnosprawność lub długotrwała choroba rodziców,

- wyjazd rodzica za granicę,

- przebywanie opiekunów w zakładzie karnym,

- dysfunkcjonalność rodziny biologicznej związana z alkoholizmem lub narkomanią ${ }^{33}$.

W rodzinach zastępczych umieszczanych jest corocznie ponad 100 dzieci. Szczegółowe dane zaprezentowano w tabeli 3.

Tabela 3. Liczba dzieci w rodzinach zastępczych w mieście Rzeszowie w latach 2005-2014

\begin{tabular}{|c|c|}
\hline Rok & Liczba dzieci \\
\hline 2005 & 124 \\
\hline 2006 & 130 \\
\hline 2007 & 144 \\
\hline 2008 & 145 \\
\hline 2009 & 140 \\
\hline 2010 & 144 \\
\hline 2011 & 140 \\
\hline
\end{tabular}

33 Miejski Ośrodek Pomocy Społecznej w Rzeszowie, Powiatowy Program Rozwoju Pieczy Zastępczej na lata 2012-2014, Rzeszów 2012, s. 7. 


\begin{tabular}{|c|c|}
\hline Rok & Liczba dzieci \\
\hline 2012 & 129 \\
\hline 2013 & 147 \\
\hline 2014 & 155 \\
\hline
\end{tabular}

Źródło: Miejski Ośrodek Pomocy Społecznej w Rzeszowie, Program budowania lokalnego systemu opieki nad dzieckiem i rodzina w mieście Rzeszów na lata 2009-2015, Rzeszów 2009, s. 13; Miejski Ośrodek Pomocy Społecznej w Rzeszowie, Powiatowy Program Rozwoju Pieczy Zastępczej na lata 2012-2014, Rzeszów 2012, s. 8-9, Miejski Ośrodek Pomocy Społecznej w Rzeszowie, Sprawozdanie z realizacji zadań $z$ zakresu wspierania rodziny i systemu pieczy zastępczej za 2012 rok, Rzeszów 2013, s. 9; Miejski Ośrodek Pomocy Społecznej w Rzeszowie, Sprawozdanie $z$ realizacji działań z zakresu wspierania rodziny i systemu pieczy zastępczej za 2013 rok, Rzeszów 2014, s. 10. Główny Urząd Statystyczny, Bank Danych Lokalnych - Opieka nad dziećmi i młodzieżą. Rodziny zastępcze. Powiat m. Rzeszów za rok 2014, http://stat.gov. pl/bdl/app/dane_podgrup.dims?p_id=897233\&p_token=0.7033370941007369 (31.05.2015).

Najczęściej występującym typem rodziny zastępczej jest rodzina zastępcza spokrewniona, tworzona przez dziadków i rodzeństwo, a także krewnych w linii bocznej. Najrzadziej rodzinę zastępczą tworzą osoby niespokrewnione z dzieckiem. Pod opieką rodzin zastępczych najczęściej jest jedno dziecko. Do 2011 roku w Rzeszowie nie funkcjonowały rodziny zastępcze zawodowe. W 2012 roku powstała jedna, w 2013 roku rodzin zawodowych było 5, w tym jedna rodzina pełniąca funkcję pogotowia rodzinnego oraz jedna rodzina zastępcza specjalistyczna.

Pomoc i wsparcie ze strony służb społecznych na rzecz rodzin zastępczych na terenie miasta Rzeszowa realizowane są w oparciu o Powiatowy Program Rozwoju Pieczy Zastępczej na lata 2012-2014. Działania te realizuje Zespół do Spraw Organizacji Pieczy Zastępczej Miejskiego Ośrodka Pomocy Społecznej w Rzeszowie, który zarządzeniem Prezydenta Miasta Rzeszowa z dnia 27 grudnia 2011 roku został wyznaczony na organizatora pieczy zastępczej na terenie powiatu miasto Rzeszów. Działania podejmowane na rzecz wsparcia rodzin zastępczych funkcjonujących w Rzeszowie związane są przede wszystkim z pomocą w zakresie przezwyciężania problemów opiekuńczo-wychowawczych. W szczególności ta forma pomocy wiąże się z:

- zapewnieniem wsparcia dzieciom umieszczonym w pieczy zastępczej oraz osobom pełniącym funkcję rodziny zastępczej pomocy w sytuacji problemów opiekuńczo-wychowawczych poprzez pomoc psychologiczną, pedagogiczną i prawną,

- zapewnieniem pomocy i wsparcia rodzinom zastępczym w formie grup wsparcia, szkoły dla rodziców oraz rodzin pomocowych,

- organizowaniem pomocy wolontariuszy, 
- zapewnieniem rodzinom zastępczym szkoleń podnoszących ich kompetencje opiekuńczo-wychowawcze,

- wspieraniem w uzyskaniu pomocy materialnej,

- współpracą z ośrodkami pomocy społecznej, powiatowymi centrami pomocy rodzinie, sądem rodzinnym, Kościołem katolickim i innymi Kościołami oraz organizacjami pozarządowymi działającymi na rzecz dziecka i rodziny,

- udzielaniem informacji o instytucjach świadczących pomoc na rzecz dziecka i rodziny ${ }^{34}$.

Rodziny zastępcze mogą korzystać także z pomocy osób trzecich. Zgodnie z Ustawą z 9 czerwca 2011 roku o wspieraniu rodziny i systemie pieczy zastępczej na wniosek rodziny mogą być one wspierane przez rodziny pomocowe, zwłaszcza w sytuacji czasowego niesprawowania opieki w związku z wypoczynkiem, udziałem w szkoleniach lub pobytem w szpitalu oraz niespodziewanych trudności lub zdarzeń losowych (art. 73). Rodziną pomocową może być rodzina zastępcza niezawodowa oraz rodzina zastępcza zawodowa, a także osoba prowadząca rodzinny dom dziecka, ponadto małżonkowie i osoby niepozostające w związku małżeńskim, którzy przeszli odpowiednie przeszkolenie (art. 74 pkt. 1). Ponadto, jeśli w rodzinie zastępczej zawodowej lub rodzinie zastępczej niezawodowej przebywa więcej niż 3 dzieci, na wniosek rodziny zatrudnia się osobę do pomocy przy sprawowaniu opieki nad dziećmi i przy pracach gospodarskich (art. 57 pkt. 1a).

Rodziny zastępcze, na ich wniosek, zostają objęte opieką koordynatora rodzinnej pieczy zastępczej, pozostałe rodziny - opieką organizatora rodzinnej pieczy zastępczej. Do głównych zadań koordynatora w zakresie wsparcia i pomocy rodzinom zastępczym należy:

- udzielanie pomocy w zakresie zadań wynikających z pieczy zastępczej,

- przygotowanie planu pomocy dziecku we współpracy z asystentem rodziny i rodziną zastępczą,

- zapewnienie rodzinom zastępczym dostępu do specjalistycznej pomocy dla dzieci, w tym psychologicznej, reedukacyjnej i rehabilitacyjnej (art. 77 pkt. 3).

Zadania organizatora pieczy zastępczej w zakresie wsparcia rodziny zastępczej skupiają się m.in. na:

- zapewnieniu rodzinom szkoleń podnoszących ich kwalifikacje,

- zapewnieniu pomocy w ramach grup wsparcia oraz prowadzeniu poradnictwa i terapii dla rodziców zastępczych, ich dzieci oraz dzieci będących pod ich opieką,

34 Tamże, s. 25. 
- zapewnieniu pomocy prawnej, zwłaszcza w zakresie prawa rodzinnego, szkoleniu i wspieraniu psychologiczno-pedagogicznym rodziców zastępczych,

- zapewnieniu rodzicom zastępczym zawodowym i rodzicom zastępczym niezawodowym poradnictwa, którego celem jest zachowanie i wzmocnienie ich kompetencji oraz przeciwdziałanie zjawisku wypalenia zawodowego (art. 76 pkt. 4).

W ramach pomocy i wsparcia dla rodzin zastępczych oraz ich dzieci i dzieci umieszczonych w pieczy zastępczej Zespół do Spraw Organizacji Pieczy Zastępczej Miejskiego Ośrodka Pomocy Społecznej w Rzeszowie w latach 20122013 osób podejmował różnorodne działania. Skupiały się one przede wszystkim na pomocy w rozwiązywaniu problemów opiekuńczo-wychowawczych i obejmowały m.in. szkolenia, grupę wsparcia, poradnictwo, specjalistyczną terapię, pomoc psychologiczną, reedukacyjną i rehabilitacyjną, grupę socjoterapeutyczną dla dzieci umieszczonych w pieczy zastępczej oraz pomoc wolontariuszy. Wybrane działania w zakresie pomocy i wsparcia rodzin zastępczych przedstawiono w tabeli 4 na następnej stronie.

Działania wspierające na rzecz rodzin zastępczych prowadzą także władze miejskie oraz organizacje pozarządowe, działające na terenie miasta Rzeszów. Od 2013 roku rodziny zastępcze mogą korzystać z miejskiego programu „Rodzina Wielodzietna3+; Rodzina zastępcza”, w którego ramach członkom rodzin zastępczych oferowane są przez instytucje miejskie i prywatnych partnerów programu różnego rodzaju ulgi, zwolnienia i preferencje ${ }^{35}$. Program ten ma na celu m.in. promocję rodzin zastępczych i działań na rzecz wzmocnienia ich kondycji, poprawę warunków ich życia oraz zwiększenie szans rozwojowych i życiowych dzieci i młodzieży wychowujących się w rodzinach zastępczych. Dodatkowym wsparciem i formą pomocy dla rodzin zastępczych jest też działalność Stowarzyszenia dla Rodziców Zastępczych „Drugi Dom”, założonego przez członków grupy wsparcia działającej przy Miejskim Ośrodku Pomocy Społecznej w Rzeszowie.

\section{Podsumowanie}

Działania wspierające i pomocowe na rzecz funkcjonujących w środowisku lokalnym rodzin zastępczych są bardzo istotne $\mathrm{z}$ punktu widzenia zastępczej opieki na dzieckiem. Ze względu na rodzinny charakter pieczy rodzina zastęp-

35 Uchwała Nr LVI/1068/2013 Rady Miasta Rzeszowa z dnia 9 lipca 2013 roku w sprawie wprowadzenia na terenie Rzeszowa Programu „Rodzina Wielodzietna 3 +; Rodzina zastępcza”. 





cza ma szansę zapewnić dziecku nie tylko odpowiednie warunki bytowe, optymalny rozwój, ale także zaspokoić jego indywidualne potrzeby, w tym miłości, bezpieczeństwa i przynależności. Jest to trudny proces, poprzedzony procedurą kwalifikacji w przypadku rodzin zastępczych niezawodowych i zawodowych oraz specjalistycznymi szkoleniami, pomagającymi przygotować się do roli rodzica zastępczego. Jednak nawet najlepsze przygotowanie teoretyczne nie jest wystarczające w sytuacji pojawienia się trudności i problemów o zróżnicowanym podłożu. W takiej sytuacji niezbędne staje się systemowe wsparcie zajmujących się pomocą dziecku i rodzinie profesjonalistów - m.in. organizatora i koordynatora rodzinnej pieczy zastępczej, asystenta rodziny, pracowników socjalnych, pedagogów, psychologów, terapeutów, oraz podjęcie kompleksowych działań, mających na celu przezwyciężenie pojawiających się trudności. Rodzina zastępcza, mimo iż pobyt dziecka jest tylko czasowy, nie powinna czuć się osamotniona w zapewnieniu jak najlepszej opieki dziecku, które nie może być $\mathrm{z}$ własnymi rodzicami.

\section{Bibliografia}

Baron B., Rodzicielstwo zastępcze w historii i praktyce, [w:] Świat rodziny. Perspektywa interdyscyplinarna wobec wyzwań i zagrożeń, red. J. M. Garbula, A. Zakrzewska, W. Sawczuk, Toruń 2013.

Brakuje rodzin zastępczych na Podkarpaciu, http://wiadomosci.onet.pl/rzeszow/brakujerodzin-zastepczych-na-podkarparpaciu/pmrx3 (31.05.2015).

Brągiel J., Kurcz A., Sytuacja szkolna dzieci z rodzin zastępczych, [w:] W świecie dziecka osieroconego i rodziny adopcyjnej, red. A. Kalus, Opole 2003.

Główny Urząd Statystyczny, Bank Danych Lokalnych - Opieka nad dziećmi i młodzieżą. Rodziny zastępcze. Powiat m. Rzeszów za rok 2014, http://stat.gov.pl/bdl/app/dane_pod grup.dims?p_id=897233\&p_token=0.7033370941007369 (31.05.2015).

Jamrożek M., Matyjas B., Rodzina zastępcza, [w:] Encyklopedia pedagogiczna XXI wieku, t. 5, pod red. T. Pilcha, Wydawnictwo Akademickie „Żak”, Warszawa 2006.

Kodeks Etyczny Rodzin Zastępczych, [w:] Pomoc dzieciom i rodzinie w środowisku lokalnym. Debata o nowym systemie, red. M. Racław-Markowska, Warszawa 2005.

Krajewska B., Instytucje wsparcia dziecka i rodziny. Zagadnienia podstawowe, Kraków 2009.

Łuczyński A., Rodziny zastępcze - ich rola i zadania w systemie opieki całkowitej, [w:] Opieka i wychowanie dzieci sierocych w Polsce, red. J. Kuźma, Kraków 2007.

Maciaszek J., Model rodzicielskiej opieki zastępczej - założenia a ich praktyczna realizacja, [w:] Przemiany współczesnej rodziny polskiej, red. S. Pelc, Rzeszów 2010.

Matejek J., Działalność ośrodków adopcyjno-opiekuńczych w procesie przygotowania i wspierania rodzin zastępczych, Kraków 2008. 
Miejski Ośrodek Pomocy Społecznej w Rzeszowie, Powiatowy Program Rozwoju Pieczy Zastępczej na lata 2012-2014, Rzeszów 2012.

Miejski Ośrodek Pomocy Społecznej w Rzeszowie, Program budowania lokalnego systemu opieki nad dzieckiem i rodzina w mieście Rzeszów na lata 2009-2015, Rzeszów 2009.

Miejski Ośrodek Pomocy Społecznej w Rzeszowie, Sprawozdanie z realizacji zadań z zakresu wspierania rodziny i systemu pieczy zastępczej za 2013 rok, Rzeszów 2014.

Miejski Ośrodek Pomocy Społecznej w Rzeszowie, Sprawozdanie z realizacji zadań z zakresu wspierania rodziny i systemu pieczy zastępczej za 2012 rok, Rzeszów 2013.

Ministerstwo Sprawiedliwości, Małoletni pod opieka - rodziny zastępcze (karty Opm) w latach 1989-2014; http://isws.ms.gov.pl/pl/baza-statystyczna/opracowania-wieloletnie/ (24.06.2015).

Ministerstwo Sprawiedliwości, Placówki opiekuńczo-wychowawcze-umieszczenie małoletnich w latach 1989-2014, http://isws.ms.gov.pl/pl/baza-statystyczna/opracowania-wieloletnie/ (24.06.2015).

Sarnacka B., Sieroctwo dziecka i możliwości jego kompensacji w systemie opieki, [w:] Pedagog i pracownik socjalny wobec wyzwań współczesności, red. A. Błasiak, E. Dybowska, N. Pikuła, Kraków 2012.

Sobisiak P., „Nic o nas bez nas”. W stronę partnerskiego modelu wspótpracy rodzin zastępczych z pracownikami socjalnymi, [w:] Pomoc dzieciom i rodzinie w środowisku lokalnym. Debata o nowym systemie, red. M. Racław-Markowska, Warszawa 2005.

Stelmaszuk Z. W., Dziecko w rodzinie zastępczej, [w:] Rodzice i dzieci - psychologiczny obraz sytuacji problemowych, red. E. Milewska, A. Szymanowska, Warszawa 2000.

Stojecka-Zuber R., Badora S., Opieka nad dziećmi w rodzinach zastępczych powiatu tarnobrzeskiego, [w:] Przeciw sieroctwu. Zapobieganie, opieka, pomoc instytucjonalna, red. S. Badora, Tarnobrzeg 2009.

Stowarzyszenie Zastępczego Rodzicielstwa, Karta Podstawowych Praw Rodziców Zastępczych, [w:] Pomoc dzieciom i rodzinie w środowisku lokalnym. Debata o nowym systemie, red. M. Racław-Markowska, Warszawa 2005.

Szlachcińska B., Coraz więcej dzieci potrzebuje rodziców zastępczych, http://supernowosci24. $\mathrm{pl} /$ coraz-wiecej-dzieci-potrzebuje-rodzicow-zastepczych/ (31.05.2015).

Trawkowska D., Pomoc społeczna i jej pracownicy wobec problemów pracy socjalnej z rodzinami zastępczymi, [w:] Pomoc dzieciom i rodzinie w środowisku lokalnym. Debata o nowym systemie, red. M. Racław-Markowska, Warszawa 2005.

Uchwała Nr LVI/1068/2013 Rady Miasta Rzeszowa z dnia 9 lipca 2013 roku w sprawie wprowadzenia na terenie Rzeszowa Programu „Rodzina Wielodzietna 3 +; Rodzina zastępcza”.

Ustawa z dnia 9 czerwca 2011 roku o wspieraniu rodziny i systemie pieczy zastępczej (Dz. U. 2011 nr 149 poz. 887)

Winogrodzka L., Rodziny zastepcze i ich dzieci, Lublin 2007. 